\title{
Keunggulan Bersaing Berkelanjutan Berbasis Inovasi dan Kearifan Lokal Pada Usaha Kecil dan Menengah Makanan Tradisional di Pekanbaru
}

\author{
Rosmayani $^{1 *}$, Annisa Mardatillah ${ }^{2}$ \\ ${ }^{1,2}$ Administrasi Bisnis, Fakultas Ilmu Sosial dan Ilmu Politik Universitas Islam Riau \\ *Koresponden E-mail: rosmayani@soc.uir.ac.id
}

(Diterima 01 Juni 2021|Disetujui 28 Mei 2021|Diterbitkan 18 Juli 2021)

\begin{abstract}
Business actors' competition in capturing market share has made it essential for business actors to implement sustainable competitive advantage through local wisdom and innovation. It is expected to improve product quality sustainably. This study aims to analyze sustainable competitive advantage based on local wisdom and innovation in small and medium enterprises of Riau Malay traditional food in Pekanbaru. The research method used is qualitative with observation, interview, and literary techniques. The sampling technique used was purposive sampling on ten business actors and triangulation as the analysis technique in this study. This study's findings are that local wisdom factors and product innovation are a source of sustainable competitive advantage in the micro and small business sector of Riau Malay traditional food in Pekanbaru. Although innovations made in traditional Riau Malay food products, this has not made the product more homogeneous but still thick with its uniqueness and authenticity. The resources owned's heterogeneity is reflected in local knowledge, local skills, local resources, and local values in traditional Riau Malay food products, a differentiator that competitors cannot imitate.
\end{abstract}

Keywords: Sustainable competitive advantage, Innovation, Traditional food, Local wisdom

\section{PENDAHULUAN}

Sektor Usaha Kecil Menengah (UKM) adalah usaha kerakyatan yang paling banyak dilakukan masyarakat dan berperan penting dalam perekonomian Indonesia. Khususnya dalam rangka mewujudkan sistem perekonomian kerakyatan.

Usaha Kecil Menengah umumnya memiliki keunggulan dalam bidang yang memanfaatkan sumber daya alam dan padat karya, misalnya pertanian tanaman pangan, perkebunan, peternakan, perikanan,perdagangan. Salah satu bentuk Usaha Kecil dan Menengah yang dilakukan adalah industri makanan.Industri makanan merupakan bentuk usaha yang menjadi salah satu alternatif usaha industri pengolahan yang dapat memberikan pendapatan untuk pelaku usahanya selain itu tentu saja dapat membantu pemerintah dalam hal penyerapan tenaga kerja, pemerataan distribusi hasil- hasil pembangunan, dan penanggulangan kemiskinan. Peningkatan jumlah unit Usaha Kecil Menengah akan diikuti dengan tingkat penyerapan tenaga kerja pula.Perkembangan unit Usaha Kecil Menengah memang tidak secepat unit usaha lainnya namun Usaha Kecil Menengah ini merupakan unit usaha yang mampu bertahan dalam kondisi krisis ekonomi.

Pelanggan saat ini cenderung menginginkan produk inovatif yang ditawarkan perusahaan untuk memenuhi keinginan mereka.Sesuatu yang inovatif akan memberikan kesan dan pengalaman baru bagi pelanggan dalam menikmati produk. Bagi perusahaan, melakukan inovasi produk yang sesuai dengan keinginan pelanggan adalah suatu keberhasilan yang berarti dapat lebih unggul dibandingkan pesaing. Inovasi pada dasarnya harus dilakukan dengan perencanaan yang baik dan cermat oleh karena itu perusahaan dituntut memiliki intuisi dan keahlian dalam mengenali perubahan selera pelanggan. Hal ini diharapkan kegiatan inovasi yang dilakukan akan tepat sasaran sesuai selera pelanggan.

Kota Pekanbaru merupakan salah satu daerah yang memiliki banyak industri makanan tradisional. Jenis makanan tradisional yang dipasarkan beraneka macam mulai dari panganan kering dan basah. Beberapa contoh makanan tradisional yang dipasarkan adalah keripik singkong, keripik tempe, keripik pisang, kue bangkit, kue kemojo, lempuk, kue talam dan lain sebagainya. Berdasarkan informasi atau data yang diperoleh dari dinas koperasian UMKM kota pekanbaru adalah sebanyak 67.728 UMKM dipekanbaru dihampir seluruh lini usaha. Namun ada 4 lini dengan jumlah UMKM terbesar yang bergerak di sektor yang sama yaitu produksi (2.042 UMKM), perdagangan (12.345 UMKM), jasa (3.145 UMKM) dan industri (1.795 UMKM) dan sektor lainnya sebanyak 48.402 UMKM. Dari keseluruhan data jumlah UMKM tersebut sebanyak 352 Usaha Kecil dan Menengah merupakan golongan industri pangan yang terdaftar hingga tahun 2016 dari berbagai jenis usaha yang ada di Kota Pekanbaru.

Industri makanan tradisional di Pekanbaru saat ini memiliki tempat tersendiri di hati masyarakat meskipun makanan-makanan yang berasal dari luar kota Pekanbaru hingga luar negeri seperti makanan import 
dari negara tetangga Malaysia, Singapura dan Thailand turut meramaikan persaingan di pasar industri makanan disini. Meskipun makanan tradisional masih diterima dengan baik oleh selera masyarakat kita tidak dapat memungkiri adanya perubahan selera dari sebagaian masyarakat lain yang menuntut kualitas produk melalui cita rasa yang lebih moderen. Keunggulan Bersaing Berkelanjutan perusahaan dapat diperoleh jika perusahaan memiliki perbedaan sumber daya dengan perusahaan pesaing. Sumber daya organisasi tersebut yaitu memiliki nilai (valuable), langka (rare), tidak dapat ditiru (in-imitable) dan sulit digantikan (nonsubstitutable) (Barney, 2007).

Makanan tradisional Melayu di Pekanbaru saat ini telah mengalami perkembangan inovasi untuk memperbaiki kebutuhan dan keinginan pelanggan. Inovasi yang dilakukan memberikan tambahan fitur baru yang menarik bagi minat pelanggan seperti inovasi dari varian rasa, bentuk, dan inovasi proses produksi yang sudah menggunakan teknologi untuk menghasilkan perkembangan produk yang dapat masuk pada potensi pasar saat ini. Inovasi pemasaran telah dilakukan juga oleh pelaku usaha makanan tradisional Melayu di Pekanbaru meskipun demikian inovasi yang dilakukan tersebut belum tersentuh secara optimal. Masih terdapat dimensi lain yang belum di lakukan sehingga optimalisasi dapat dicapai untuk menghasilkan perkembangan fitur produk yang lebih baik dan mampu bersaing unggul berkelanjutan. Selain itu kondisi perkembangan inovasi yang dilakukan selama ini tetap mengandalkan nilai-nilai keaslian produk yang diolah dari pengetahuan lokal dan ketrampilan lokal pelaku usaha.

Nilai-nilai keaslian produk makanan tradisional Melayu di Pekanbaru lahir dari sejarah warisan kuliner masa lalu yang diturunkan dari generasi ke generasi. Setiap jenis makanan tradisional tersebut mengandung makna yang tidak lepas dari sejarah budaya Melayu yang Islami. Sehingga dalam proses pengolahannya tetap mengkedepankan metode dari pengetahuan lokal dan ketrampilan lokal berdasarkan ajaran tempo dulu. Meskipun demikian pelaku usaha tidak menutup diri dalam upayanya melakukan perkembangan inovasi produk dan inovasi proses untuk mendapatkan peluang pasar saat ini.

Pencapaian keunggulan bersaing berkelanjutan menurut (Barney, 2007), ditentukan peran sumber daya yang terdiri modal manusia, modal struktural dan modal relasional untuk menciptakan nilai yang bermanfaat bagi konsumennya, sulit ditiru oleh para pesaingnya dan didukung oleh manajemen perusahaan. Perusahaan yang berorientasi pada pasar akan fokus pada kebutuhan eksternal, keinganan dan permintaan pasar. Hal ini sebagai budaya organisasi dan dasar perusahaan dalam menyusun strategi perusahaan untuk mencapai tujuannya. Dalam rangka mendukung budaya perusahaan yang berorientasi pada pasar, perusahaan harus memiliki komitmen dan partisipasi dari seluruh anggota perusahaan. Ini penting untuk menjadi proses pembelajaran berke- lanjutan bagi perusahaan untuk memberikan nilai tambah yang lebih dan berbeda bagi pelanggan. Khususnya ini menjadi sangat penting saat kondisi pasar menghadapi tingkat persaingan yang sangat tinggi yang menyebabkan UKM perlu menerapkan strategi produk yang inovatif untuk mampu bersaing unggul memberikan kepuasan pelanggan.

Menurut (Amabile, 1996) inovasi merupakan suatu proses baru dari penerapan gagasan kreatif. Perusahaan diharapkan mampu melakukan penerapan gagasan pemikiran-pemikiran baru untuk menghadapi persaingan. Selanjutnya ( Gatignon \& Xuereb, 1997; Dismawan, 2016; Kotler, 2009), menyatakan bahwa inovasi produk perlu memperhatikan 3 hal yaitu keunikan produk, keunggulan produk dan biaya produk. Selain itu indikator inovasi yang lain dapat dilihat dari daya kreatifitas, inovasi teknism perubahan desain, perubahan distribusi dan sistem pembayaran.

Kegagalan dalam inovasi produk seringkali karena adanya kesalahan dalam melakukan desain produk, kurang tepat memprediksi persaingan, biaya produksi yang mahal diluar perhitungan yang diperkirakan sebelumnya. Lambat dalam melakukan perubahan inovasi produk yang tidak sejalan dengan pertumbuhan produk yang ada dipasar juga menjadi alasan kegagalan perusahaan.

Keunggulan bersaing menjadi keunggulan bersaing berkelanjutan dengan penekanan pada aspek internal perusahaan yang lebih ditekankan oleh (Barney, 2001) lebih menekankan pada pendekatan aspek eksternal dan tidak mengacu pada aspek internal perusahaan untuk mencapai keunggulan kompetitif.

Para peneliti pendukung Resources Based View berpendapat bahwa sumber daya sangat penting sebagai sumber keunggulan kompetitif berkelanjutan. Sumber daya tersebut disebut sebagai aset strategis (Amit \& Schoemaker, 1993), kompetensi inti (Prahalad \& Hamel, 1994) dan Distinctive Competencies (Papp \& Luftman, 1995). Penemuan empiris pada bidang keunggulan bersaing berkelanjutan UMK menunjukkan bahwa kemampuan menciptakan daya saing ditentukan oleh seberapa jauh perusahaan mampu mengelola sumber dayanya (firm resources). .

Menurut ( Barney, 1991; 2001; 2007) keunggulan bersaing berkelanjutan dapat dicapai jika heterogenitas perusahaan tinggi dengan memiliki unsur value, rare resources, in-imitable dan nonsubstitutable. Sumber daya tersebut terdiri dari modal manusia, modal relasional dan modal struktural (Barney, 2007).

Kearifan lokal tergolong dalam sumber daya yang tidak berwujud (Das \& Teng, 2000) dapat diartikan sebagai pandangan hidup dan pengetahuan serta berbagai strategi kehidupan yang berwujud aktivitas dalam menjawab masalah untuk pemenuhan kebutuhan mereka. Kearifan lokal merupakan kebijaksanaan atau nilai luhur yang terkandung dalam kekayaan-kekayaan budaya lokal seperti tradisi, petatah-petitih dan semboyan hidup (Sartini, 2004). 
Kearifan dalam arti luas tidak hanya berupa norma dan nilai budaya, melainkan segala unsur gagasan, termasuk yang berimplikasi pada teknologi, penanganan kesehatan, dan estetika. Pengetahuan lokal dan ketrampilan lokal merupakan unsur gagasan yang mengandung nilai-nilai keaslian budaya lokal sebagai bentuk orisinalitas yang tidak dimiliki daerah lain sehingga akan lebih mudah bagi perusahaan mencapai keunggulan bersaing berkelanjutan (Ife, 2002; Mardatillah et.al., 2020).

Dari fenomena yang terjadi pada UKM makanan tradisional di Kota Pekanbaru maka dapat ditarik kesimpulan bahwa keunggulan bersaing produk yang inovatif dengan produk sejenis menarik untuk ditelaah lebih lanjut dalam ruang lingkup yang berbeda sehingga dapat memberikan konstribusi pada perkembangan UKM makanan tradisional berbasis pada keaslian nilai-nilai kearifan lokal.

\section{BAHAN DAN METODE}

Teknik analisis data pada penelitian ini adalah kualitatif (studi kasus), untuk menjawab faktor- faktor pendorong dan penghambat pengembangan inovasi untuk mencapai keunggulan bersaing berkelanjutan usaha kecil dan menengah makanan tradisional Melayu berbasis kearifan lokal di Pekanbaru. Selanjutnya untuk menjawab bagaimana solusi nya terkait menghadapi hambatan tersebut dilihat dari inovasi dan kearifan lokal. Wawancara mendalam dilakukan pada informan penelitian ini diperoleh dengan teknik purposive sampling terhadap 10 pelaku usaha kecil dan menengah makanan tradisional Melayu di Pekanbaru. Analisa data menggunakan teknik tringulasi. Wawancara mendalam dilakukan untuk memperoleh informasi mendalam terkait inovasi dan kearifan lokal untuk mencapai keunggulan bersaing berkelanjutan pada usaha kecil dan menengah makanan tradisional Melayu Riau di Pekanbaru baru selama ini.

\section{HASIL DAN PEMBAHASAN}

Produk makanan Melayu di Pekanbaru selama perkembangannya telah berupaya melakukan inovasi untuk mengikuti perubahan selera pasar dengan tatap mengutamakan nilai-nilai keaslian daerah, hal ini sejalan dengan penelitian (Lee \& Hsieh, 2010) bahwa inovasi adalah strategi untuk menarik minat dan daya beli konsumen. Meskipun demikian kemampuan inovasi masih sangat terbatas dibandingkan dengan produk sejenis karena masih terbatasnya tenaga profesional yang dapat mendukung hal ini. Hal ini seperti yang disampaikan oleh pelaku usaha saat wawancara : "sejauh ini kami sudah melakukan inovasi dengan mengembangkan varian rasa dan bentuk meskipun keaslian cita rasa tradisional tetap kami jaga. Kendala kami karena masih kurangnya tenaga kerja yang bias membantu inovasi kedepan lebih baik dan modal."

Kemampuan inovasi usaha kecil dan menengah makanan tradisional Melayu di Pekanbaru selama ini menggunakan teknologi dan alat yang masih tradisional meskipun demikian sudah mampu melakukan inovasi secara teknis, pembuatan desain, daya kretatifitas dan distribusi. Teknologi moderen digunakan untuk inovasi teknis seperti cetakan kue yang sudah moderen, alat pengocok bahan kue dan alat pemanggang. Selain itu para pelaku usaha sudah berinovasi dari bahan baku yang digunakan, bahan baku adalah salah satu faktor produksi penting dalam proses produksi sehingga menghasilkan produk makanan yang lebih variatif dari segi rasa namun tetap menampilkan nilai-nilai keaslian lokal.

Inovasi yang sudah dilakukan pada produk makanan tradisional melayu riau ini misalnya dengan melakukan penambahan varian rasa dan bentuk makanan. Selain itu juga dilakukan beberapa perubahan metode cara mengolah makanan dengan menggunakan teknologi modern seperti pemanggang listrik dan pengocok telur listrik. Meskipun demikian pelaku usaha makanan tradisional tetap berupaya untuk tidak menghilangkan nilai-nilai keaslian yang terkandung dalam makanan tersebut sebagai ciri khas makanan tradisional melayu.

Konsep ekonomi sejauh ini menilai manusia sebagai homo economicus dimana manusia harus menerapkan prinsip ekonomi melalui optimalisasi pemanfaatan sumber daya untuk hasil yang maksimal. Pelaku usaha diharapkan tidak hanya mementingkan laba atau keuntungan namun juga memasukkan dimensi spiritualitas dalam bisnis agar semakin bermanfaat. Terkait dengan hal tersebut pelaku usaha dalam melakukan inovasi tetap mengkedepankan sumber daya lokal baik itu dari lingkungan internal perusahaan dan ekternal perusahaan. Misalnya dari penggunaan bahan baku yang dimaksud adalah dengan memadukan bahan baku tradisional dan bahan baku moderen misalnya penambahan varian rasa baru seperti essens green tea. Bahan baku utama produk makanan mengutamakan sumberdaya lokal yang tersedia secara alami dengan pengembangan fitur inovasi yang sesuai dengan kebutuhan dan keinginan konsumen. Sebagai contoh macam-macam inovasi yang sudah dilakukan dengan tetap mengutamakan nilai-nilai kearifan lokal pada tabel 1. 
Tabel 1. Jenis Makanan Tradisional Melayu Berbasis Kearifan Lokal.

\begin{tabular}{|c|c|c|c|}
\hline No & Jenis Makanan & Nilai Kearifan Lokal & Inovasi \\
\hline 1 & Bolu Kemojo & $\begin{array}{l}\text { Tidak menggunakan } \\
\text { pengawet karena } \\
\text { kandungan manis pada } \\
\text { gula asli sebagai pengawet } \\
\text { alami. } \\
\text { Menggunakan pewarna alami dari daun suji atau pan- } \\
\text { dan untuk aroma dan rasa pandan. } \\
\text { Menggunakan kocokan telur manual tanpa mesin kare- } \\
\text { na dipercaya akan merubah struktur konsistensi kue } \\
\text { jika diolah dengan mesin mixer. }\end{array}$ & $\begin{array}{l}\text { Inovasi rasa modern } \\
\text { seperti rasa coklat, } \\
\text { durian, jagung. Mes- } \\
\text { kipun demikian tetap } \\
\text { mengutamakan unsur } \\
\text { alami dari durian, } \\
\text { jagung, dan coklat asli } \\
\text { bukan essens buatan. } \\
\text { Inovasi bentuk, sebe- } \\
\text { lumnya hanya ada } \\
\text { ukuran besar saat ini } \\
\text { sudah ada bentuk } \\
\text { mini. }\end{array}$ \\
\hline 2. & Kue Bangkit & $\begin{array}{l}\text { Menggunakan Santan kelapa alami. } \\
\text { Menggunakan tepung tapioka alami } \\
\text { Menggunakan jeruk purut alami sebagai varian rasa } \\
\text { khas jeruk purut, kacang alami untuk varian kacang. } \\
\text { Tanpa bahan pengawet }\end{array}$ & $\begin{array}{l}\text { Inovasi pada penam- } \\
\text { bahan varian rasa } \\
\text { seperti coklat, kacang, } \\
\text { durian, pandan. } \\
\text { Inovasi pada penam- } \\
\text { bahan pada variasi } \\
\text { bentuk kue. }\end{array}$ \\
\hline 3 & Kue Talam Ubi & $\begin{array}{l}\text { Menggunakan Ubi asli organik. } \\
\text { Menggunakan Kelapa organic } \\
\text { Menggunakan Gula Enau organik } \\
\text { Menggunakan pembungkus kemasan alami dari daun } \\
\text { pisang } \\
\text { Tanpa pengawet }\end{array}$ & $\begin{array}{l}\text { Inovasi pada penam- } \\
\text { bahan bentuk kema- } \\
\text { san, saat ini ada yang } \\
\text { menggunakan ke- } \\
\text { masaan kotak. }\end{array}$ \\
\hline 4 & $\begin{array}{l}\text { Kue Melaka/ } \\
\text { Onde-onde }\end{array}$ & $\begin{array}{l}\text { Menggunakan daun suji atau pandan alami sebagai rasa } \\
\text { dan warna makanan. } \\
\text { Menggunakan gula enau alami. } \\
\text { Menggunakan parutan kelapa alami. } \\
\text { Menggunakan tepung ketan alami } \\
\text { Tanpa pengawet }\end{array}$ & $\begin{array}{l}\text { Inovasi pada penam- } \\
\text { bahan varian rasa yai- } \\
\text { tu penambahan ubi } \\
\text { merah. }\end{array}$ \\
\hline 5 & $\begin{array}{l}\text { Lempuk Duri- } \\
\text { an }\end{array}$ & $\begin{array}{l}\text { Menggunakan bahan dasar durian asli organik. } \\
\text { Menggunakan gula alami. } \\
\text { Tanpa bahan pengawet } \\
\text { Menggunakan kemasan daun alami }\end{array}$ & $\begin{array}{l}\text { Inovasi pada penam- } \\
\text { bahan varian bentuk } \\
\text { makanan } \\
\text { Inovasi pada penam- } \\
\text { bahan varian bentuk } \\
\text { kemasan }\end{array}$ \\
\hline
\end{tabular}

Sumber : Olahan hasil penelitian, 2021

Selain itu inovasi bentuk makanan juga sudah dilakukan misalnya dengan memproduksi makanan dengan berbagai ukuran dan bentuk. Pendidikan dan pelatihan selama ini diberikan oleh Dinas Perindustrian dan Perdagangan Provinsi Riau dan kabupaten/kota turut membantu dalam perkembangan usaha meskipun dirasakan masih perlu pengembangan pelatihan lebih lanjut yang tepat sasaran sesuai kebutuhan pelaku usaha. Hal ini sejalan dengan pemikiran (Lee \& Hsieh, 2010) bahwa inovasi adalah strategi daya saing untuk meningkatkan minat konsumen. Namun sayangnya kemampuan inovasi masih sangat terbatas dibandingkan dengan produk sejenis karena masih terbatasnya tenaga profesional yang dapat mendukung hal ini.

Kemampuan keunggulan bersaing berkelanjutan pelaku usaha makanan tradisional Melayu di
Pekanbaru sejauh ini dilihat dari faktor-faktor pendorong dan penghambat diperoleh berdasarkan temuan penelitian diketahui bahwa masih banyak pelaku usaha yang tidak melakukan survei pasar. Artinya bahwa pelaku usaha dalam memproduksi produk tidak melihat berdasarkan keinginan konsumen. Pelaku usaha relatif melakukan produksi dengan selera yang sudah biasa dilakukan meski demikian inovasi sudah ada dilakukan walaupun belum maksimal. Namun demikian kreativitas dan inovasi tersebut tidak jarang belum dilakukan berdasarkan keinginan pelanggan atau konsumen, meskipun pada beberapa pelaku usaha sudah berupaya mengikuti tren selera pasar dengan tetap mempertahankan nilai-nilai keaslian produk.

Hasil penelitian ini sejalan dengan Barney (1991, 2001; Terziovski, 2010) bahwa keunggulan 
bersaing berkelanjutan suatu perusahaan dapat dicapai dengan memiliki heterogenitas yang tinggi dengan unsur value, rare resources, in-imitable dan nonsubstitutable.

Produk makanan tradisional Melayu memiliki daya tarik tersendiri bagi konsumen, baik sebagai produk konsumsi sehari-hari dan juga untuk kebutuhan buah tangan bagi konsumen untuk dibawa keluar daerah Pekanbaru. Konsumen dari luar daerah memiliki minat dan daya beli terhadap produk makanan tradisional Melayu di Pekanbaru ini karena cita rasa dan sejarah dari latar belakang makanan Melayu ini yang tidak dimiliki daerah lain sebagai bentuk orisinalitas produk sebagai nilai manfaat lebih bagi konsumen.

Keaslian produk makanan tradisional Melayu di Pekanbaru dibuat dengan sentuhan nilai-nilai lokal Melayu yang kemudian menjadi pengetahuan lokal dan ketrampilan lokal pelaku usaha diperoleh secara turun temurun sebagai warisan local (Mardatillah et al., 2019). Pengetahuan pengolahan bahan baku lokal makanan tradisional Melayu di Pekanbaru berikut teknik pengolahannya secara tradisional tidak dengan mudah dimiliki oleh pelaku usaha dari daerah lain. Hal ini disebabkan setiap daerah memiliki pengetahuan inti lokal dan ketrampilan lokal yang berbeda dipengaruhi oleh latar belakang sejarah budaya sebelumnya. Hal ini sejalan dengan (Nonaka \& Takeuchi, 1995) bahwa pengetahuan yang diperoleh dari pengalaman langsung sebelumnya disebut tacit knowledge akan melekat lebih baik didalam diri seseorang sebagai pengetahuan yang tidak mudah dimiliki oleh orang lain.

Nilai-nilai keaslian yang terkandung pada makanan tradisional Melayu. Unsur gagasan dalam proses produksi makanan tradisional Melayu di Pekanbaru terkait dengan pengetahuan lokal dan ketrampilan lokal yang merupakan unsur gagasan mengandung nilai-nilai keaslian budaya lokal sebagai bentuk orisinalitas yang tidak dimiliki daerah lain sehingga akan lebih mudah bagi perusahaan mencapai keunggulan bersaing berkelanjutan (Ife, 2002; Mardatillah et.al., 2020).

\section{SIMPULAN}

Hasil penelitian keunggulan bersaing berkelanjutan berbasis inovasi dan kearifan lokal pada usaha kecil dan menengah makanan tradisional Melayu di Pekanbaru memiliki aspek kekuatan produk latar belakang sejarah nilai-nilai keaslian budaya melayu islami yang terkandung didalam produk tersebut. Inovasi produk dan proses yang dilakukan mengkedepankan esensi orisinalitas sebagai nilai tambah bagi pelanggan. Nilai tambah ini menjadi kompetensi keunggulan produk makanan tradisional Melayu di Pekanbaru yang lebih bernilai, unik, tidak mudah ditiru dan tidak mudah digantikan. Hal ini menjadi kekuatan yang tidak dapat berpindah pada perusahaan lain. Meskipun demikian masih terdapat kelemahan yaitu masih terbatasnya tenaga kerja yang profesional dalam pengembangan inovasi produk. Potensi sumber daya lokal adalah faktor penting dalam strategi pengembangan inovasi usaha. Pengetahuan lokal dan ketrampilan lokal tenaga kerja yang tidak mudah ditiru dan tidak dapat digantikan sebagai sumber kekuatan untuk menghasilkan produk yang berheterogenitas tinggi sehingga tidak mudah ditiru oleh pesaing.

\section{DAFTAR PUSTAKA}

Amabile, T. M. (1996). Assesing The Work Environment For Creativity. Academy of Management Journal., 1154-1184.

Amit, R., \& Schoemaker, P. J. (1993). Strategic assets and organisational rent. Strategic Management Journal, 14(June 1990), 33-46. https://doi.org/10.1002/smj.4250140105

Barney, J. (1991). Firm Resources and Sustained Competitive Advantage. Journal of Management, 17(1), 99-120. https://doi.org/10.1177/014920639101700108

Barney, J. B. (2007). Gaining and Sustaining Competitive Advantage. 3ed. Pearson International Education Inc., Publishing as Prentice-Hall Upper Saddle River, New Jersey, 07458, USA.

Barney, J. B. O. S. U. (2001). 4. Resource-based theories of competitive advantage by Barney 2001.pdf. Journal of Management, 27, 643-650.

Das, T. K., \& Teng, B.-S. (2000). A Resource-Based Theory of Strategic Alliances. Journal of Management, 26(1), 31-61. https://doi.org/10.1177/014920630002600105

Dismawan, R. (2016). Pengaruh kreativitas produk dan inovasi produk terhadap keunggulan bersaing. Jurnal Manajemen., 2(3).

Hubert Gatignon \& Jean-Marc Xuereb. (1997). Strategic Orientation of the Firm and New Product Performance. Journal of Marketing Research Publications, Inc., 34(1), 77-90.

Ife, jim. (2002). Community Development: Community Based alternative in an Age of globalization. Australia: Parson education.

Kotler, P. (2009). Manajemen Pemasaran: Analisis, Perencanaan dan Implementasi Dan Kontrol,. Erlangga, Jakarta.

Lee, J., \& Hsieh, C. (2010). A Research In Relating Entrepreneurship, Marketing Capability, Innovative Capability And Sustained Competitive Advantage. 8(9), 109-120.

Mardatillah, A., Raharja, S. J., Hermanto, B., \& Herawaty, T. (2019). Riau Malay food culture in Pekanbaru, Riau Indonesia: Commodification, authenticity, and sustainability in a global business era. Journal of Ethnic Foods, 6(1), 1-10. https://doi.org/10.1186/s42779-019-0005-7 
Mardatillah, A., \& Ramadani, S. A. (2020). Sustainable Competitive Advantage of Riau Malay Weaving Industry Based on Local Wisdom. International Research Journal of Business Studies, 13(3), 227-240.

Nonaka, I. \& Takeuchi, H. (1995). The KnowledgeCreating Company: How Japanese Companies Create the Dynamics of Innovation. Oxford University Press, Oxford.

Papp, R., \& Luftman, J. (1995). Business and I / T Strategic Alignment: New Perspectives and Assessments Business and I / $\mathrm{T}$ Strategic Alignment
Prahalad, C.K. \& Hamel, G. (1994). Strategy as a field of study: why search for a new paradigm. Strategic Management Journal, 15, 5-16.

Sartini. (2004). Menggali Kearifan Lokal Nusantara Sebuah Kajian FIlsafati. Jurnal Filsafat, 14(2), 111-120.

Terziovski, M. (2010). Innovation practice and its performance implications in small and mediumenterprises, (SMEs) in the manufacturing sector: a 81 resource-based view. Strategic Management Journal, 31(8), 892-900. 